\title{
高温・酸化/還元環境下における機械的特性評価法の開発*
}

\author{
渡辺 智 $^{* 1}$, 佐藤一永 ${ }^{* 2}$, 武山陽平 ${ }^{* 3}$, 井口史匡 ${ }^{* 4}$, 八代圭司 ${ }^{* 5}$ \\ 雨澤浩史 ${ }^{* 3}$, 湯上浩雄 ${ }^{* 4}$, 橋田俊之 ${ }^{* 6}$, 水崎純一郎 ${ }^{* 5}$, 川田達也 ${ }^{* 3}$

\section{Mechanical Properties Evaluation Method for Non-Stoichiometric Materials under High Temperature and Oxidizing/Reducing Conditions} \\ Satoshi WATANABE ${ }^{* 1}$, Kazuhisa SATO, Yohei TAKEYAMA, Fumitada IGUCHI, \\ Keiji YASHIRO, Koji AMEZAWA, Hiroo YUGAMI, Toshiyuki HASHIDA, \\ Junichiro MIZUSAKI and Tatsuya KAWADA \\ ${ }^{*}$ Graduate School of Environmental Studies, Tohoku University \\ 6-6-01 Aramaki-Aoba, Aoba-ku, Sendai, Miyagi, 980-8579, JAPAN
}

For the commercialization of solid oxide fuel cell (SOFC), in addition to the electrochemical reliability, it is also important to ensure the mechanical reliability of SOFC. Thus, the establishment of a suitable mechanical testing method under various temperatures and oxygen partial pressure conditions is a prerequisite for the development of reliable SOFCs. In this study, the in-situ mechanical testing method was developed in order to investigate mechanical property (i.e.: Elastic modulus and Fracture strength, Creep and Fatigue property) of solid oxide fuel cells components under high oxidizing/reducing environments. And mechanical property of gadolinium doped ceria $\left(\mathrm{Gd}_{0.1} \mathrm{Ce}_{0.9} \mathrm{O}_{2-\delta}\right.$; GDC) as oxygen non-stoichiometric compounds were evaluated in oxygen partial pressures under reducing conditions by developed In-situ mechanical testing machine. The experimental results of the investigation of elastic modulus and fracture strength on the SOFC components, the fracture stress of GDC were almost constant regardless of oxygen partial pressure, while elastic modulus decreased with decreasing oxygen partial pressure in reducing atmospheres. Mechanical properties of SOFC materials should be characterized by in-situ method because these results are different to quench method.

Key Words : In-Situ Mechanical Testing Method, Oxygen Partial Pressure, Functional Oxide, Non-Stoichiometry, Oxygen Vacancy (Defect), Solid Oxide Fuel Cell (SOFC)

\section{1. 緒 言}

固体酸化物燃料電池 (Solid Oxide Fuel Cell :SOFC) は極めて高い発電効率が実現可能であるため, 次世代 型発電システムとして注目されている。そのため実用化に向けた高性能 SOFC の開発が世界各国で進んでい る. SOFC 概念図(単セル)を図 1 に示す. SOFC 基本構造は正極/電解質/負極の 3 層で構成されており, 正 極でイオン化した $\mathrm{O}^{2-}$ は負極へ拡散し, 負極で電子を外部回路に手放す．電子は外部回路を負極から正極に流 れることにより発電する，その際，電解質内部のイオン輸送は電極間の電気化学ポテンシャル勾配(酸化・還 元等)が駆動力となる. 従って, 構成材料は電池内部での構成位置や運転条件によって唒される環境(化学ポテ ンシャル)がそれぞれ異なる. SOFC 構成材料では酸化・還元環境中で格子欠陥濃度, 結晶構造等(格子定数を 含む)が大きく変化する材料(遷移金属を含む材料)が用いられるため, 運転条件下における材料特性(電気化学

\footnotetext{
*原稿受付 2011 年 2 月 21 日

*1正員, 東北大学大学院 環境科学研究科（干980-8579 宮城県仙台市青葉区荒巻字青葉 6-6-01）

*2正員, 東北大学 多元物質科学研究所

*3 東北大学大学院 環境科学研究科

${ }^{*} 4$ 正員, 東北大学大学院 工学研究科

*5 東北大学 多元物質科学研究所

*6正員, フェロー, 東北大学大学院 工学研究科

E-mail: s-watanabe@ee.mech.tohoku.ac.jp
} 
特性・物理的特性・機械的特性)を把握することは長期信頼性のあるデバイス設計につながる極めて重要な情 報となる. そのためSOFC 構成材料に対する電気化学的特性や物理的特性などの環境依存性について研究が 行われている ${ }^{(1)-(4)}$. しかし, 構造体としての耐久性を決める機械的性質の環境依存性についての研究は立ち 遅れている．停滞理由としては，第一に評価装置そのものがないことである．単一環境制御，つまりそれぞ れ試験温度, 雾囲気のみを制御した評価報告(5)-(7)はあるが厳密には SOFC 動作環境中の特性とは言えない。 新たに評価装置を作製する場合も材料試験では試験試料に対して負荷を与えるものが多く, 機械式可動部を 伴う.この可動部動作を含めての気密性確保は技術的になかなか難しい. 第二に試験試行回数の多さである. 通常セラミックス材の機械的性質評価を行う場合, 同一条件で複数回の材料試験を行う必要がある ${ }^{(8)}$. 最後 に試験片形状により均一試料を得るまでの時間が大きく変わること.SOFC では環境に応じて材料特性が変 化しうる材料を用いる，そのため試験環境を変化させた時, 試料内部・外部で物理・化学的特性が異ならな い均一試料を得るまでに要する時間は試料体積・形状で大きく異なる。これら課題が解決され，より実動作 環境に近い状態で容易に材料評価ができれば構成材料の機械的性質評価に新たな知見が生まれるであろう。 また機械的・電気化学的・物理的因子間の相互作用を総合的に評価 ${ }^{(9)}$ する上で有益なアイテムと成りうる. 本論文では, 酸素分圧(酸素欠陥濃度), 試験温度が制御可能でかつその環境内で材料試験を行うことで, 機械 的性質(縦弾性係数, 破壊強度, クリープ特性ならびに疲労特性)などがその場で評価が可能な試験装置の開発 を行ったので報告する. また環境変化に伴い, 材料中の格子欠陥濃度, 結晶構造, 電子構造等が変化するこ とで機械的特性にどのような影響を及ぼすかを明らかにするため, 不定比性酸化物材料(酸素分圧の変化によ り材料中の酸素欠陥濃度が増減する)であるセリア系酸化物を評価対象材料として検討を行った。 また, 高 温・酸素濃度制御環境下で保持した試料を急冷し, 酸素欠陥濃度や結晶構造を凍結した場合と環境下で直接 材料試験を行った場合の機械的特性(縦弾性係数ならびに破壊強度)比較を行ったのでこれも併せて報告する.

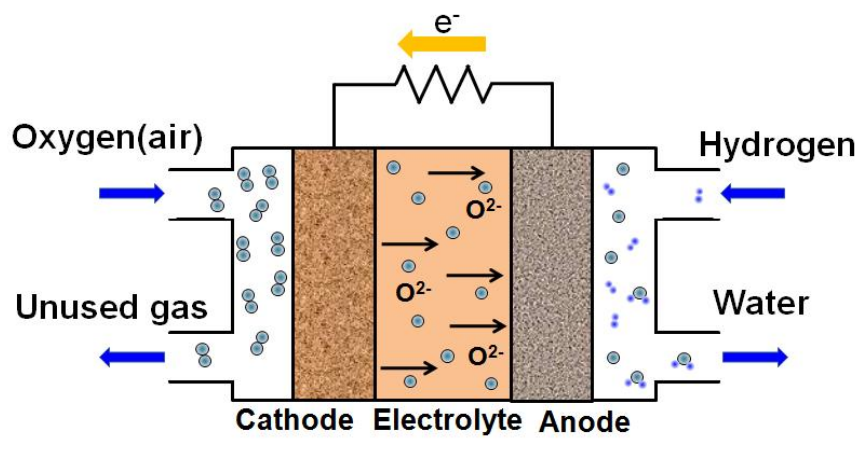

Fig.1 SOFC operating principle

\section{2. 複合環境制御型材料試験装置の開発}

\section{$2 \cdot 1$ 装置概要}

本研究では室温から $1000^{\circ} \mathrm{C}$ まで温度制御が可能でかつ酸素分圧が約 $1 \mathrm{~atm} \sim 10^{-25} \mathrm{~atm}$ まで制御できる環境 槽を開発し, 引張・圧縮・疲労負荷が可能な万能試験装置(5565 型：INSTRON)に設置した。このことで試験 温度, ガス条件(ガス種・流量・濃度)が制御された環境の内で材料試験が可能となった. 図 2 に環境槽概略図 を示す.試験部は耐熱性およびガス気密性の確保からアルミナ管(石英ガラス管)を用いて周囲を覆う仕組みと なっている. また，アルミナ管-金属上下フランジ接続部は $\mathrm{O}$ リングで固定し，その接続部を水冷すること で高温でもガス気密性が保てるように設計した。本装置ガス系統については真空排気による圧力上昇チェッ クを実施し，ガスリークがないことを確認した。後述するが本装置では材料評価方法として小型パンチ (Small-punch：SP)試験法 ${ }^{(10)}$ を採用している. また，本研究ではセラミックスを始めとした脆性材料が評価対 象となっているため, 破壊に至るまでの試料変形量は $20 \mu \mathrm{m}$ と非常に小さい, そのため, 環境槽の剛性は 極めて重要となる。本機作製にあたり, 試験試料に約 $200 \mathrm{~N}$ の荷重が負荷された時, 環境槽全体の変形量が $1 \mu \mathrm{m}$ 以下となるよう, 有限要素シミュレーションにより環境槽構成部材寸法を算出し, 試験機剛性を確保し た。 また，レーザー変位計を下部フランジから吊り下げるように設置し, 試料変形量を治具-レーザー変位計 
の相対距離に置き換えて測定することで環境槽の変形を実験データに反映させない変位計測を実現した．本 論文では, SOFC 構成材料を試験対象としているが, 固体高分子形燃料電池(PEFC), リチウムイオン電池, 水素吸蔵合金等で使用される材料に関しても評価が可能である.

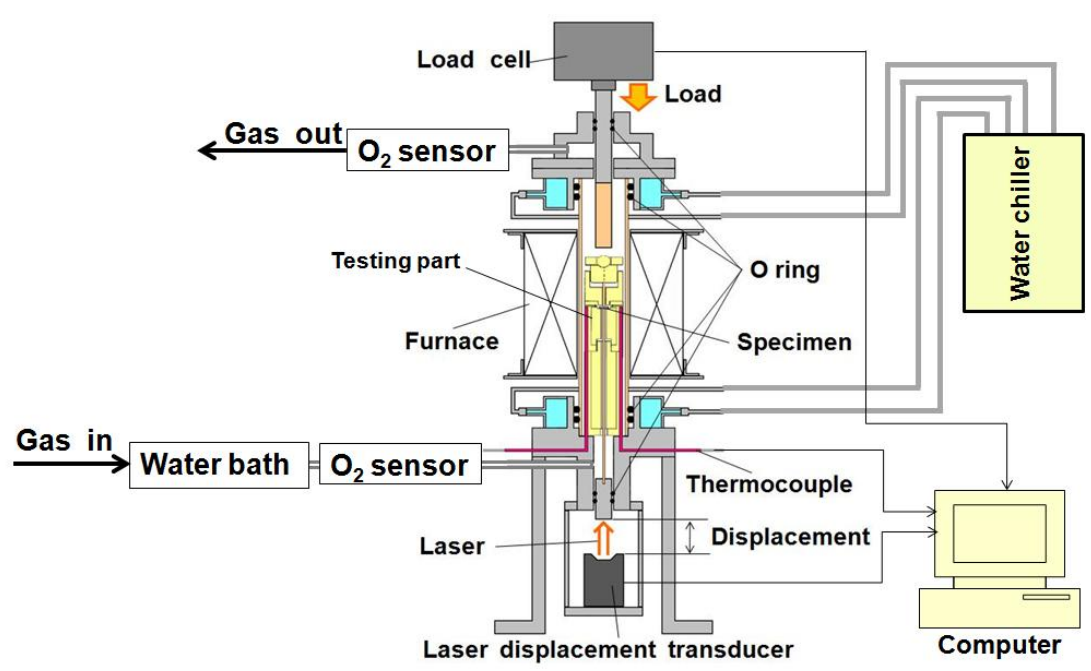

Fig.2 Schematic illustration of developed mechanical testing equipment

\section{$2 \cdot 2$ 酸素分圧制御方法}

本装置ガス供給系について述べる，ガス供給系ブロック線図を図 3 に示す．SOFC 動作環境は温度域がお およそ $500^{\circ} \mathrm{C} \sim 1000^{\circ} \mathrm{C}$, 酸素分圧は $1 \sim 10^{-25} \mathrm{~atm}$ の範囲で稼働する. 上記ガス環境を再現するに当たり試験 装置に接続された使用可能ガス(純 $\mathrm{Ar}$, 純 $\mathrm{CO}_{2}, 0.1 \% \mathrm{CO}_{-} \mathrm{CO}_{2}, 10 \% \mathrm{CO}_{-} \mathrm{CO}_{2}, 1 \% \mathrm{H}_{2}-\mathrm{Ar}, \quad$ 純 $\mathrm{H}_{2}, \quad$ 純 $\mathrm{O}_{2}$, $1 \% \mathrm{O}_{2}-\mathrm{Ar}, \quad 100 \mathrm{ppmO}_{2}$ - $\mathrm{Ar}$ の 9 種)を選択し，MFC(SEC-B40 および SEC-E40: HORIBA STEC 社製)を用いて選 択したガス流量を調整することで酸素分圧は制御される. また還元 $\left(\mathrm{H}_{2}\right.$ 系 $)$ ガスについても規定水温に調整さ れた水槽を通すことで水蒸気量が調整され，酸素分圧の制御が可能となる．調整されたガスは環境槽へ導入 されるが，環境槽ガス導入口およびガス排出口にはそれぞれジルコニア酸素センサーを設置してあり，酸素 濃度を確認しながら実験を行うことができる.

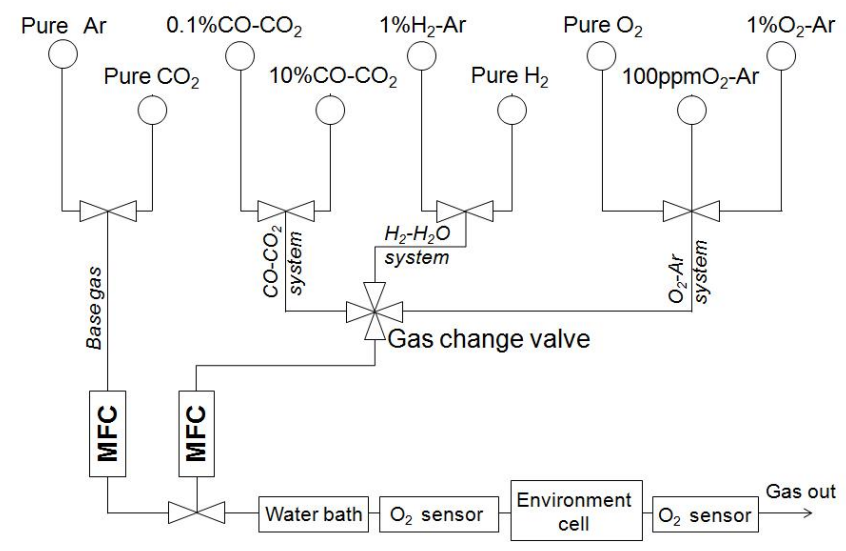

Fig.3 Schematic illustration of block diagram gas system

\section{$2 \cdot 3$ 荷重負荷方法}

材料試験機には万能試験機(5565 型：INSTRON)，およびロードセル(Static Load Cell, $\pm 1 \mathrm{kN}:$ INSTRON)を用 いた．クロスヘッド速度は 0.001-1000 mm/min まで設定が可能である. 試験は変位制御で行い, 試料に対す る荷重負荷はロードセルに接続されている円柱型の押込棒にて行う(図 4). 尚, 本機では治具を変更すること により，引張試験・曲げ試験・圧縮試験・疲労試験・クリープ試験等の各種試験を行うことができる．押込 
棒は荷重負荷, 荷重測定のという意味で試料とロードセルの連結役であり, また環境槽接続部ではガスシー ル役でもある. そのため一般的な O リングを用いてガスシールを行うと抵抗力(摩擦力)が誤差荷重として測 定されてしまうため荷重計測精度が悪くなってしまう。そこで可動部に対してシール面積が比較的小さく, 油圧用パッキンとして広く用いられているリップ型 O リングを用いて試験中の摩擦力低減を試みた。 0.01 , $0.05, \quad 0.1,0.5, \quad 1.0 \mathrm{~mm} / \mathrm{min}$, それぞれのクロスヘッド速度に対して環境槽と押込棒の接続箇所で生じる摩 擦抵抗を測定した。測定結果を図 5 に示す.

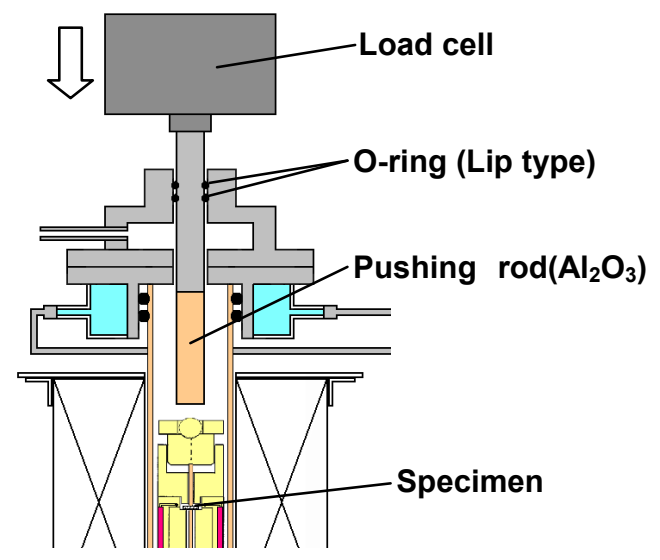

Fig.4 Schematic illustration of loading part in developed mechanical testing equipment

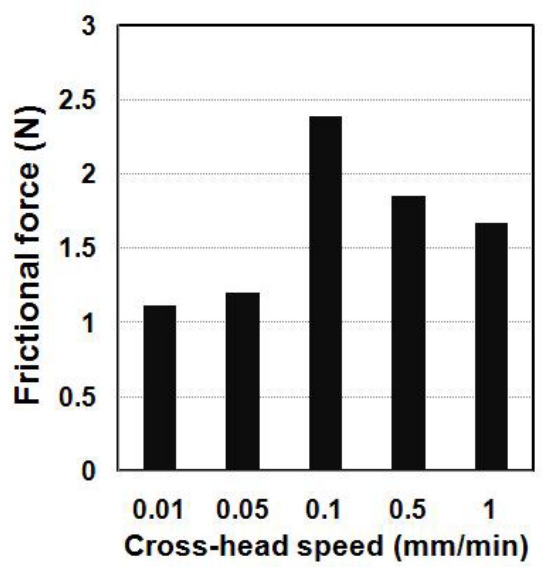

Fig.5 Frictional force as a function of cross-head speed.

クロスヘッド速度 $0.1 \mathrm{~mm} / \mathrm{min}$ の時, 計測される摩擦力は最大で約 $2.5 \mathrm{~N}$, クロスヘッド速度 $0.05 \mathrm{~mm} / \mathrm{min}$ 以下では約 $1 \mathrm{~N}$ と低下していた。この結果を踏まえ，本研究では脆性材料を評価対象としており破断に至る までの試料変形量が小さく, 実験時のクロスヘッド速度は比較的遅い方が望ましいこと, また, 摩擦抵抗が 極力小さいことを勘案し，クロスヘッド速度 $0.05 \mathrm{~mm} / \mathrm{min}$ で実験を行うこととした.

\section{$2 \cdot 4$ 試験部}

本研究では，機械的性質評価方法として小型パンチ(Small-punch：SP)試験法 ${ }^{(10)}$ を採用した．SP 試験法は従 来金属材料に用いられ試験法であるが奥田ら ${ }^{(10)}$, 斉藤ら ${ }^{(11)}$ は脆性材料における破壊特性值の測定に適応，拡 張し，その有効性を示している．本機のようにガス気密性，温度管理，荷重および試料変形量計測の精度に 制約を受ける装置に対しては非常に有効な試験方法となる。あわせて $\mathrm{SP}$ 試験法で用いられる試料は引張/圧

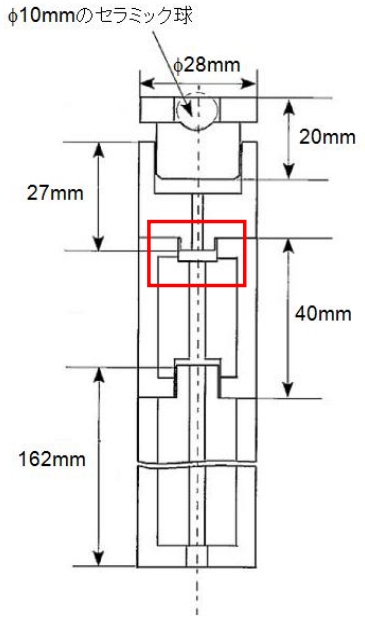

Fig.6 Schematic illustration of testing part

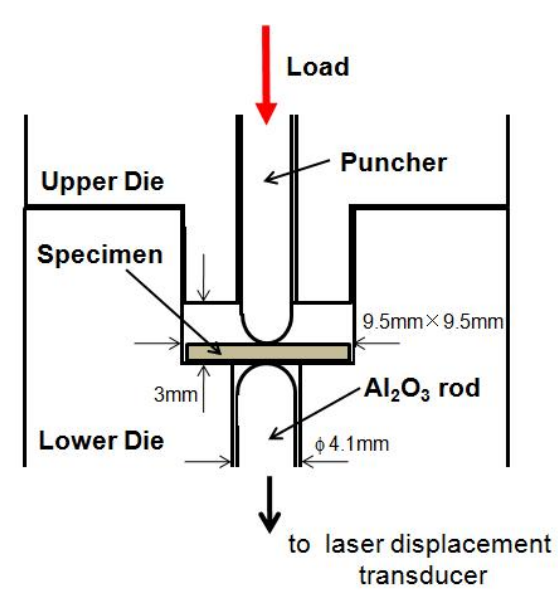

Fig.7 Schematic illustration of testing part around specimen 

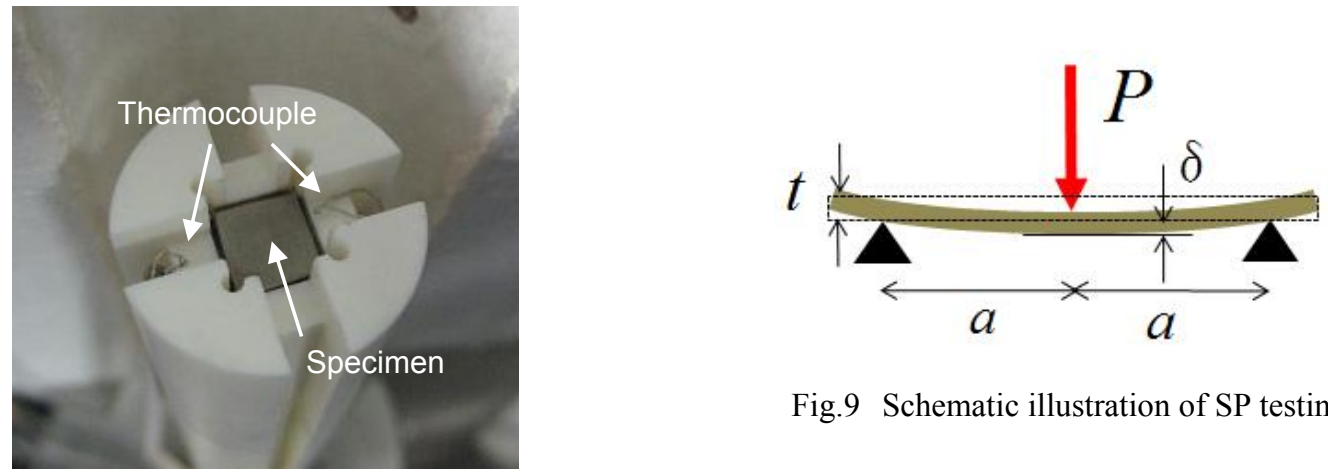

Fig.9 Schematic illustration of SP testing

Fig.8 Photograph of specimen set on the lower die

縮試験で一般的に用いられる試験片よりも小型で, 試料作製も比較的容易である. また化学的な定常状態(化 学緩和)を得る時間を短縮できるという利点もある. 本機における試験部(SP 試験で使用する治具)の組立図を 図 6 に示す. 治具は全て $\mathrm{Al}_{2} \mathrm{O}_{3}$ で作製しており高温環境でも十分に治具剛性が確保するものを使用した. 図 中赤で示された箇所に試験片を設置する. 尚, 図 6 中赤で示した箇所の拡大図を図 7 に示す. 試験片の固定 方法は締付けや高温試験時の熱膨張による破損防止のため単純支持方式とした. 負荷様式は先端球体 (半径 1 $\mathrm{mm})$ のパンチャーによる集中荷重負荷方式である．冶具内に設けられた試験片設置エリアは $9.5 \mathrm{~mm} \times 9.5 \mathrm{~mm}$ であり, 試験片支持用, ならびに変位計測用 $\mathrm{Al}_{2} \mathrm{O}_{3}$ ロッドの配置用として中央部には $\phi 4.1 \mathrm{~mm}$ の貫通穴が設け てある. 実際の SP 試験で試験片は治具設置面の鏡面研磨が，また試料設置面が少なくとも $44.1 \mathrm{~mm}$ より大き く, 試験片設置エリアに設けられた中央部貫通穴が試料で完全に覆われていれていることが試験片に求めら れる条件となる，そのため，試験片形状は角型また丸型試料どちらでも可能である．負荷荷重に対する試験 片変形量は $\mathrm{Al}_{2} \mathrm{O}_{3}$ ロッドを介してレーザー変位計(KEYENCE : LK-G15 およびLK-GD500)にて変位計測を行う。 治具に試験片を設置している様子を図 8 に示寸. 図 8 中に示されているが試験片近傍には環境槽内試験片近 傍の温度を計測するための熱電対を配しており, 本指示值をもって環境槽加熱ヒーターの温度調整/制御を行 っている. SP 試験で得られた荷重-変位曲線から勾配 $P / \delta$ および破断荷重 $P_{\max }$ を求め，(1)(2)式に代入するこ とで縦弾性係数 $E_{S P}$ および破断応力 $\sigma_{f S P}$ を求めることができる.

$$
\begin{gathered}
E_{S P}=f\left(\frac{t}{a}\right) \frac{3 a^{2}(1-v)(3+v)}{4 \pi t^{3}} \cdot \frac{P}{\delta} \\
\sigma_{f S P}=\frac{1}{t^{2}}(1+v)\left[0.485 \ln +0.52+\frac{3}{2 \pi(1+v)}\right] \cdot P_{\text {max }}
\end{gathered}
$$

図 9 に SP 試験概要を示す. $P$ はパンチャー荷重, $\delta$ は試験片変位, $a$ は支点間半径(ダイス半径), $t$ は板 厚, $v$ はポアソン比 $(=0.3)^{(12)}, f(t / a)$ は板厚補正係数である ${ }^{(10)}$. (1), (2)は薄板理論による無次元応力, 無次元 コンプライアンスより導出されているが，無次元コンプライアンスについては試料厚み依存性が確認されて おり, 試料厚みが増すと有限要素解析結果より求めた無次元コンプライアンスとの差異が大きくなる. 是正 方法として奥田らは補正係数を用いて試料厚み $0.1 \sim 1 \mathrm{~mm}$ で両者の補正を行っている ${ }^{(10)}$. このことから試料 厚み $0.1 \sim 1 \mathrm{~mm}$ であれば，(1)は試料厚さの影響を受けることなく縦弾性係数を算出することができる. しか し, 実際の SP 試験では試料厚さが $0.5 \mathrm{~mm}$ 以下になると破断荷重が著しく低下寸るため, 試験準備段階で試 料が破断している場合が多く見受けられる.また試料厚さ $1 \mathrm{~mm}$ 以上では無次元コンプライアンスの特性上， 誤差が増大してしまう可能性がある. 従って, 本実験では試料作製において試料厚み $0.5 \mathrm{~mm}$ 以上 $1 \mathrm{~mm}$ 未満 のものを合格品とし，試験試料として採用した. 


\section{3. 実験方法}

\section{$3 \cdot 1$ 供試材および試験片}

本試験では, 酸素分圧の変化により材料中の酸素欠陥濃度が増減する $\mathrm{Ce}_{0.9} \mathrm{Gd}_{0.1} \mathrm{O}_{2-\delta}$ を評価材料とした. 試験 片は，阿南化成（株）製の粉末により作製した．試料粉末を超鋼製ダイスに入れて，50 MPa の圧力で一軸成 形を行い，円柱状のグリーン体を作製. その後グリーン体を冷間等方圧プレス成形で $120 \mathrm{MPa}$ の加圧処理を 施した後， $1350^{\circ} \mathrm{C} て ゙ 2$ 時間焼成することにより焼結体を得た。作製した焼結体は $3 \mu \mathrm{m}$ バフ研磨により，鏡 面に仕上げた．その後，アルキメデス法により密度測定を行い，相対密度は $97 \%$ 以上のもの合格品として試 験試料とした．試験片寸法は $\phi 7.5 \mathrm{~mm}$ ，試料厚さは $0.5 \mathrm{~mm}$ 以上， $1 \mathrm{~mm}$ 未満である.

\section{$3 \cdot 2$ 急冷凍結（クエンチ）処理による機械特性評価方法}

試験片を環境制御炉内にセットし，一定量の $\mathrm{Ar}$ ガスを流すことにより，環境槽内部のガスを不活性ガス環 境に置換した。 その後, $200^{\circ} \mathrm{C} / \mathrm{h}$ で昇温し, 処理温度 $800^{\circ} \mathrm{C}$ に達した後, 酸素分圧を制御するためにガス(純 $\mathrm{H}_{2}, 1 \% \mathrm{H}_{2}-\mathrm{Ar}$, Air)で置換した. 本実験で行ったガス種および酸素分圧の関係を表 1 に示す. 環境槽のガス 導入口およびガス排出口に設置したジルコニア酸素センサーの示寸酸素分圧が安定してから試験片を炉内で 1 時間保持した。保持時間は Fick の第 1 法則から導かれる一次元の拡散に関する式(3)により決定した.

$$
t=\frac{x^{2}}{2 D}
$$

$t$ は緩和時間， $x$ は試験片厚みの $1 / 2$ の距離， $D$ は自己拡散係数である. 保持後,試験片を置いた治具を炉内か ら引き抜くことにより試料を急冷し, $800^{\circ} \mathrm{C}$ における酸素欠陥濃度を凍結した.クエンチ処理を施した試験片 は表面再酸化の影響を考慮し，不活性ガスに置換し，室温に戻った後，大気開放した．その後室温・大気環 境下でクエンチ処理した試料の SP 試験を実施した。クロスヘッド速度は $0.1 \mathrm{~mm} / \mathrm{min}$ である.

Table 1 Quench treatment condition of oxygen partial pressure

\begin{tabular}{|c|c|c|}
\hline Gas & Water bath temperature $\left({ }^{\circ} \mathrm{C}\right)$ & Oxygen partial pressure(atm) \\
\hline Air & & 0.2 \\
\hline $1 \% \mathrm{H}_{2}-99 \% \mathrm{Ar}$ & 20 & $2.4 \mathrm{E}-18$ \\
\hline Pure $\mathrm{H}_{2}$ & 20 & $2.4 \mathrm{E}-22$ \\
\hline Pure $\mathrm{H}_{2}$ & 5 & $3.2 \mathrm{E}-23$ \\
\hline
\end{tabular}

\section{$3 \cdot 3$ 高温・酸化/還元環境下における機械特性評価方法}

本研究で開発した複合環境制御型材料試験装置を用いて機械的性質の評価を行った．試験条件はクエンチ 法と同様で, 不活性ガス置換後 $200^{\circ} \mathrm{C} / \mathrm{h}$ で昇温し， $800^{\circ} \mathrm{C}$ に加熱した. 酸素分圧を制御するために規定ガス を流し, 環境槽の出口に設置したジルコニア酸素センサーの示寸酸素分圧が規定酸素分圧に到達後, 試験片 を 1 時間保持した. 本実験で行ったガス種および酸素分圧を表 2 に示す.その後, その環境中で SP 試験を実 施した。試験後は，不活性ガスに置換後， $200^{\circ} \mathrm{C} / \mathrm{h}$ で降温した。 SP 試験実施の際，クロスヘッド速度は図 5 より $0.05 \mathrm{~mm} / \mathrm{min}$ で行った.

Table 2 In-situ SP test under partial pressure

\begin{tabular}{|c|c|c|}
\hline Gas & Water bath temperature $\left({ }^{\circ} \mathrm{C}\right)$ & Oxygen partial pressure (atm) \\
\hline Pure $\mathrm{O}_{2}$ & & 1 \\
\hline $1 \% \mathrm{CO}-99 \% \mathrm{CO}_{2}$ & & $2.7 \mathrm{E}-13$ \\
\hline $1 \% \mathrm{H}_{2}-99 \% \mathrm{Ar}$ & 10 & $9.1 \mathrm{E}-19$ \\
\hline Pure $\mathrm{H}_{2}$ & 10 & $7.9 \mathrm{E}-23$ \\
\hline
\end{tabular}




\section{4. 結果および考察}

\section{$4 \cdot 1$ クエンチ処理を施した $\mathrm{Ce}_{0.9} \mathrm{Gd}_{0.1} \mathrm{O}_{2-\delta}$ の破壊ならびに弾性特性}

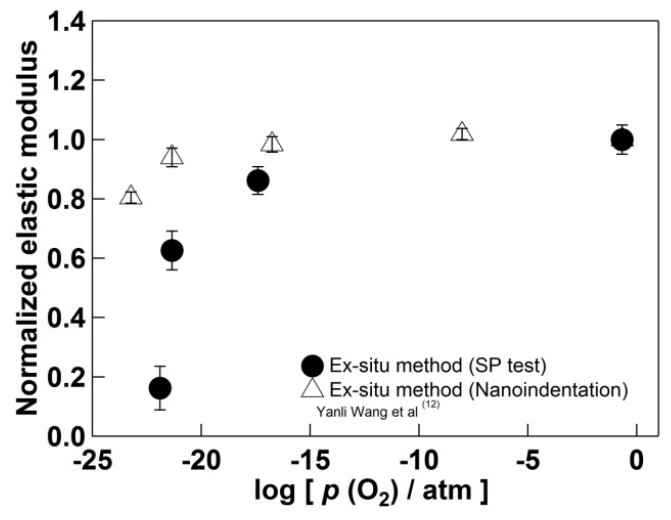

Fig.10 Normalized elastic modulus of $\mathrm{Ce}_{0.9} \mathrm{Gd}_{0.1} \mathrm{O}_{2-\delta}$ as a function of oxygen partial pressure

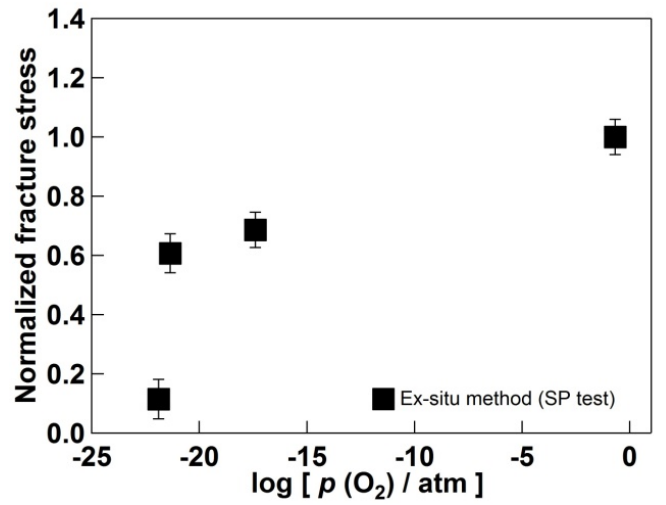

Fig.11 Normalized fracture stress of $\mathrm{Ce}_{0.9} \mathrm{Gd}_{0.1} \mathrm{O}_{2-\delta}$ as a function of oxygen partial pressure

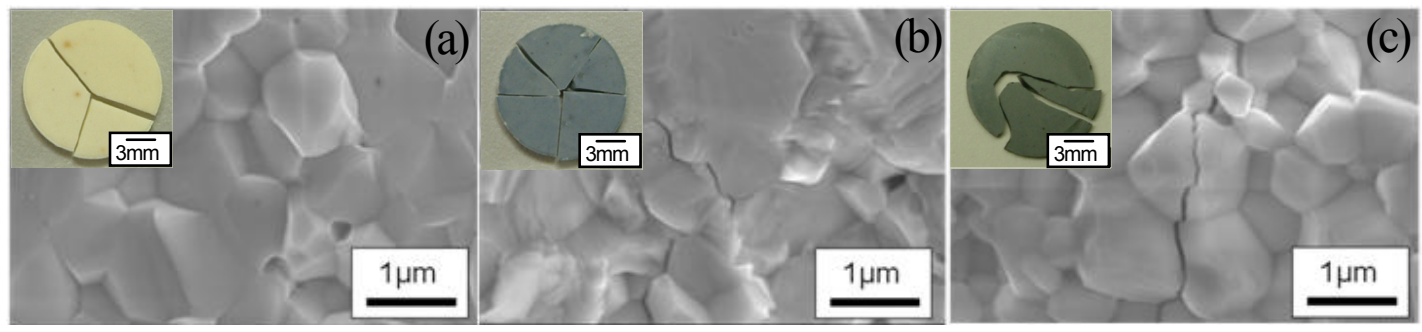

Fig.12 Photograph of specimen and FE-SEM micrograph of specimen fracture surface after SP test Quench method $\begin{array}{lll}\text { (a) } p\left(\mathrm{O}_{2}\right)=0.2 \mathrm{~atm} & \text { (b) } p\left(\mathrm{O}_{2}\right)=2.4 \times 10^{-18} \text { atm } \quad \text { (c) } p\left(\mathrm{O}_{2}\right)=2.4 \times 10^{-22} \mathrm{~atm}\end{array}$

クエンチ処理を施した試料に対する SP 試験では酸素分圧によらず全ての試料で脆性的な破壞挙動を示し た.クエンチ SP 試験により得られた各縦弾性係数および破断強度は条件毎に平均化し, 酸素分圧 $0.2 \mathrm{~atm}$ の平均縦弾性係数，平均破断強度で規格化した正規化縦弾性係数，正規化破断強度と酸素分圧の関係につい て図 10, 図 11 に示す. 尚, 各条件での実験回数は 3 回，エラーバーは標準偏差を表す. Y.Wang らは規定酸 素分圧にてクエンチ処理を施した試料表面からナノインデンテーション法によって縦弾性係数を求めている (12). Y.Wang らが求めた各酸素分圧に対寸る縦弾性係数も $0.2 \mathrm{~atm}$ での縦弾性係数で規格化し, 参考として図

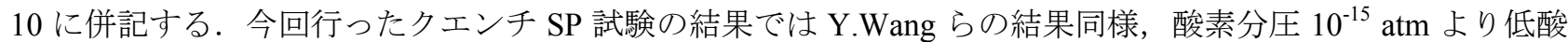
素分圧側で縦弾性係数が低下していることがわかった。破断強度については縦弾性係数で見られた傾向と同 様に，低酸素分圧側で減少していることが分かった．クエンチ SP 試験後の試料写真および破断面 SEM 像を 図 12 に示す. まず試験終了後の試料写真から酸素分圧 $0.2 \mathrm{~atm}, 2.4 \times 10^{-18} \mathrm{~atm}$ でクエンチ処理した試料では 中心から放射状にき裂が進展し，破壊が進行していたのに対し，酸素分圧 $2.4 \times 10^{-22} \mathrm{~atm}$ でクエンチ処理を施 した試料のみに中心部を迂回するようなき裂が観察された. 次に SEM 観察の結果, 酸素分圧 $0.2 \mathrm{~atm}$ でクエ ンチ処理を行った試料破断面には結晶粒の隆起が観察され，粒界で破壊が進行していることがわかる．しか し, 酸素分圧 $2.4 \times 10^{-18} \mathrm{~atm}$ のものでは結晶粒の隆起と共に結晶粒内に脆性材料破面特有のリバーパターンが 観察され，粒界破壞と粒内破壊が共に起こっていることを示唆している. 酸素分圧 $2.4 \times 10^{-22} \mathrm{~atm}$ においても $2.4 \times 10^{-18} \mathrm{~atm}$ での観察結果同様，粒界破壞，粒内破壞の形跡が多数観察された．本実験において酸素分圧が $10^{-15} \mathrm{~atm}$ より低くなると縦弾性係数および破断強度は急激に減少していたが, Y.Wang らの試験結果から得ら れた傾向とは若干異なる傾向を示している. (図 10) これは試験法の違いによるものと考えられる.つまり， クエンチ処理を施した試料に対する試験という点では共通だが，ナノインデンテーション法は局所的な機械

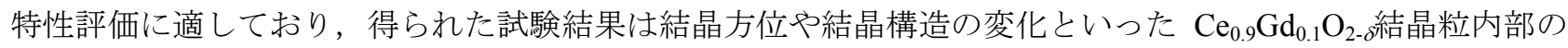
特性情報を色濃く反映している。しかし，粒界における強度/特性変化や試験試料全体での力学特性にはあま り影響されない，一方で SP 試験の場合，試験試料全体の力学特性から機械特性を求めているため，試験結果 
は結晶粒周囲の粒界における強度/特性変化に対して影響を受けやすい。実際，試験後 SEM 観察から，酸化 環境でクエンチ処理した試料では粒界破壊が支配的であったが，還元環境でクエンチ処理した試料では粒界 破壊および粒内破壊の形跡が観察されており破壊様式が異なっていた。このことが試験結果の差として現れ たものと考えられる.

\section{$4 \cdot 2$ 高温・酸化/還元環境下での $\mathrm{Ce}_{0.9} \mathbf{G d}_{0.1} \mathbf{O}_{2-\delta}$ の破壊ならびに弾性特性}

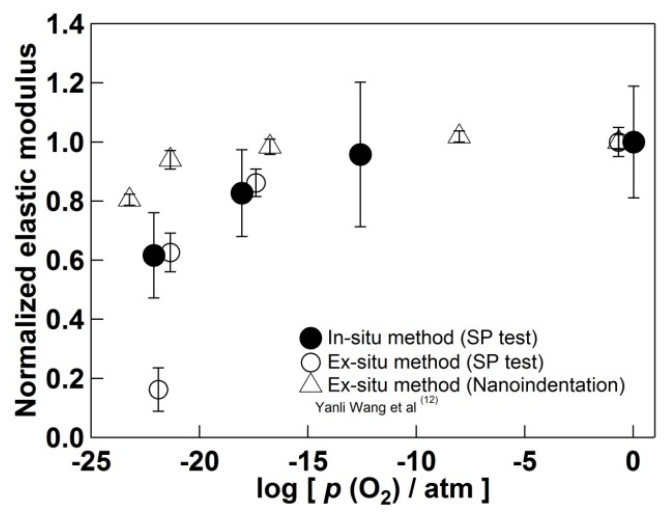

Fig.13 Normalized elastic modulus of $\mathrm{Ce}_{0.9} \mathrm{Gd}_{0.1} \mathrm{O}_{2-\delta}$ as a function of oxygen partial pressure

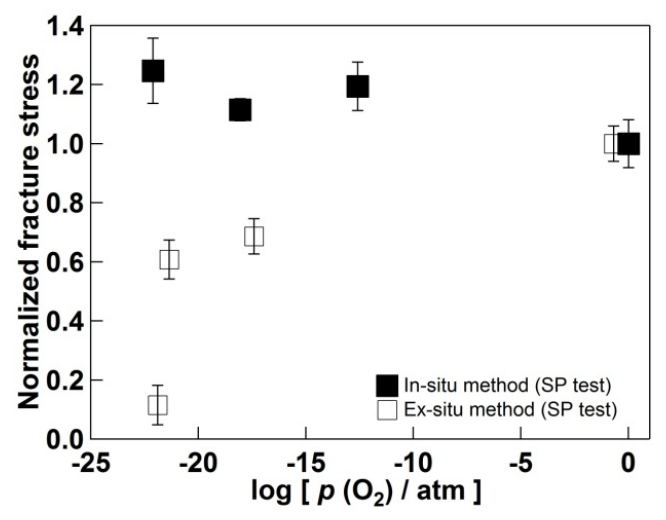

Fig.14 Normalized fracture stress of $\mathrm{Ce}_{0.9} \mathrm{Gd}_{0.1} \mathrm{O}_{2-\delta}$ as a function of oxygen partial pressure
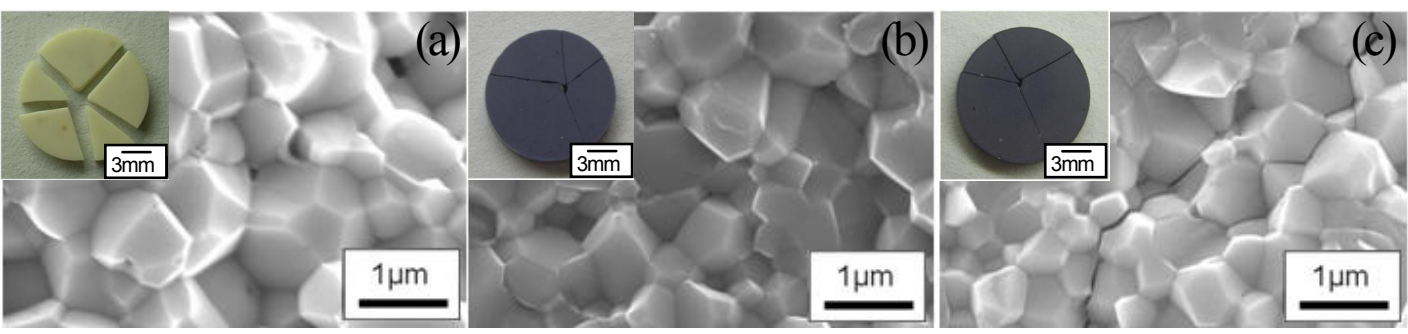

Fig.15 Photograph of specimen and FE-SEM micrograph of specimen fracture surface after in-situ SP test at $800^{\circ} \mathrm{C}$ (a) $p\left(\mathrm{O}_{2}\right)=1.0 \mathrm{~atm}$

(b) $p\left(\mathrm{O}_{2}\right)=9.1 \times 10^{-19} \mathrm{~atm}(\mathrm{c}) \quad p\left(\mathrm{O}_{2}\right)=7.9 \times 10^{-23} \mathrm{~atm}$

In-situ SP 試験においても酸素分圧によらず全ての試料で脆性的な破壊挙動を示した。 In-situ SP 試験によ り得られた各縦弾性係数および破断強度は条件毎に平均化し, 酸素分圧 $1 \mathrm{~atm}$ での平均縦弾性係数，平均破 断強度で規格化した正規化縦弾性係数, 正規化破断強度と酸素分圧の関係について図 13, 図 14 に示寸. 尚, 各条件での実験回数は 4 回, エラーバーは標準偏差を表す. $\mathrm{Ce}_{0.9} \mathrm{Gd}_{0.1} \mathrm{O}_{2-\delta}$ に対する In-situ SP 試験では, 酸素 分圧 $10^{-15} \mathrm{~atm} よ り$ 低い酸素分圧では縦弾性係数が減少するといった, 前述クエンチ SP 試験での結果とほぼ同 傾向を示した．ところが, 酸素分圧が $10^{-23} \mathrm{~atm}$ 台の試験結果においてクエンチ $\mathrm{SP}$ 試験で縦弾性係数が約 $80 \%$ 減少していたのに対して, In-situ SP 試験では約 40 \%の減少にとどまった。 また, 破断強度ではクエンチ SP 試験での結果とは異なり, 酸素分圧低下に伴い減少する傾向は示さなかった. In-situ SP 試験後の試料写真お よび破断面 SEM 像を図 15 に示す. 試験終了後の試料写真から酸素分圧 $1 \mathrm{~atm}, 9.1 \times 10^{-19} \mathrm{~atm}, 7.9 \times 10^{-23} \mathrm{~atm}$ 全ての試料では中心から放射状にき裂が生じ，破壊していた。 クエンチ SP 試験で見られた中心部を迂回する ようなき裂は観察されなかった.また, 試験後破断面の SEM 観察では, 酸素分圧 $1 \mathrm{~atm}, 9.1 \times 10^{-19} \mathrm{~atm}, 7.9 \times 10^{-23}$ $\mathrm{atm}$ 全ての試料破断面で結晶粒の隆起が観察され, 粒内破壊特有である粒内でのリバーパターンは観察され なかったことから粒界破壊が支配的であることがわかる.つまり，本実験からクエンチ SP 試験法における粒 内破壊はクエンチ処理特有の現象であることがいえる。また，これに関連して In-situ SP-クエンチ SP 試験間 で酸素分圧に対する破断強度の傾向が大きく異なった要因として, クエンチ SP 法での試験片急冷と試料表面 での再酸化による影響と考えられる。そもそもクエンチ法とは試験片を高温/還元環境で晒した後, 急冷寸る ことで試験片内部に酸素欠陥を保存する手法である. まず当該試験の場合, $800^{\circ} \mathrm{C}$ から室温へ試験試料を急 冷することで試料内部/外部の温度差から熱応力が発生し, マイクロクラック等の損傷を与えていた可能性が ある. 一般的にマイクロクラックの存在は縦弾性係数の低下を招き, 破壊勒性の低い脆性材料では破壊強度 
が低下寸る. 次にクエンチ処理後, 室温大気開放された試験片であっても試料表面は空気中の酸素によって 再酸化する ${ }^{(12)}$. 表面再酸化により試料内部に生じる応力状態を模式的に表したものを図 16 に示す. 還元され た $\mathrm{Ce}_{0.9} \mathrm{Gd}_{0.1} \mathrm{O}_{2-\delta}$ はイオン同士の結合力が弱まり, 安定なイオン間距離が増加, 全体として格子が膨張する ${ }^{(1)}$. つまり，試験片表面での再酸化層は収縮しようとするが，試験片内部の還元層に収縮を妨げられるため，引 張応力が生ずる．還元層には收縮しようとする酸化層によって圧縮応力が生ずる. (図 16(a)) 従って, 試験 試料に対してより低い酸素分圧でのクエンチ処理を施すと試料内部で生じる応力が増大寸ると考えられる. この状態で SP 試験を行うと試験片内部には図 16(b)中青で示した曲げ応力が印加される．再酸化による内部 応力と印加された曲げ応力とが加わり, 試験片内部には図 16(b)中赤で示された合成応力が生ずる. そのため, 試験片下面には実際の曲げ応力よりも大きな引張応力を生じ，破壊強度が減少したと考えられる．以上，ク エンチ処理は試料に対して急冷プロセスや酸素分圧差が生じるようなプロセスを伴うため, 厳密には環境下 での材料評価とは呼べず, 縦弾性係数や破壊強度, 破断面観察からも In-situ SP 試験結果と違いが見られた. 従って，破壊挙動を含めた機械特性評価は In-situでの試験が望ましい.
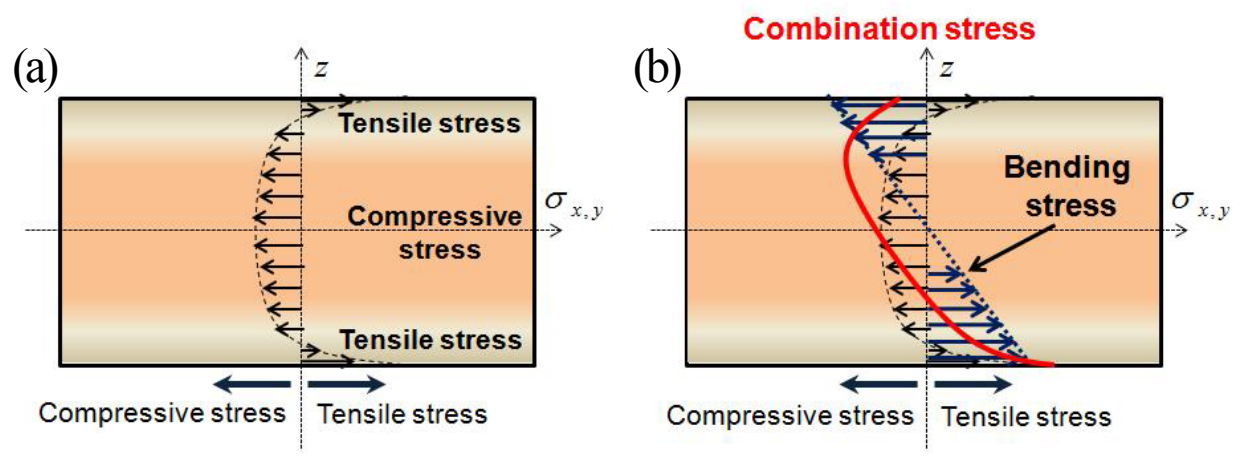

Fig. 16 Schematic illustration of specimen cross section (a) re-oxidation specimen (b) added to bending stress by SP test

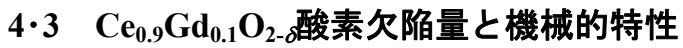

これまでの試験結果から, 酸素不定比性化合物である $\mathrm{Ce}_{0.9} \mathrm{Gd}_{0.1} \mathrm{O}_{2-\delta}$ は高温・低酸素分圧環境中では縦弾性 係数が減少していることが分かった. K.Yashiro ら ${ }^{(13)}$ にると高温・低酸素分圧環境下で $\mathrm{Ce}_{0.9} \mathrm{Gd}_{0.1} \mathrm{O}_{2-\delta}$ の酸素 欠陥濃度が増加していることを報告している。この結果を踏まえて $\mathrm{Ce}_{0.9} \mathrm{Gd}_{0.1} \mathrm{O}_{2-\delta}$ の酸素欠陥濃度 $\delta$ と縦弾性 係数との関係を図 17 に示寸. 本研究で求めた縦弾性係数は酸素分圧に起因した材料中の酸素欠損とは相関 性が見られた。つまり，酸素欠損の増減は機械的性質に影響を及ぼしていることが示唆された。

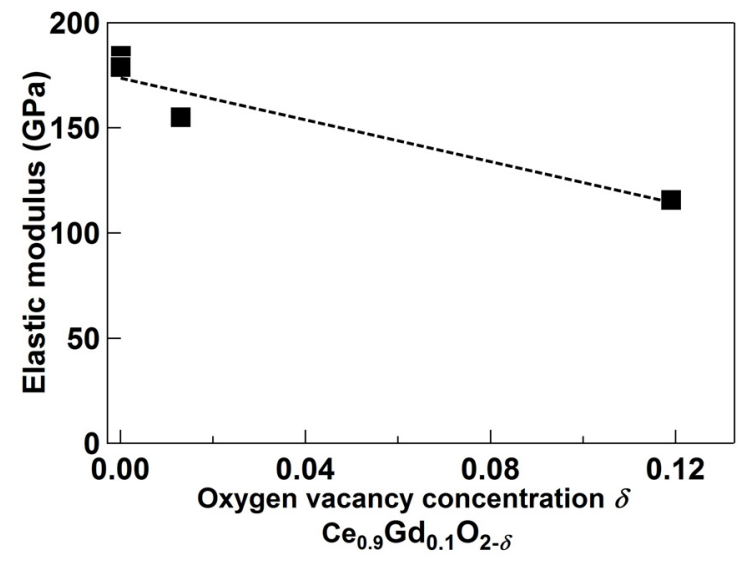

Fig. 17 Elastic modulus $\left(E_{S P}\right)$ of $\mathrm{Ce}_{0.9} \mathrm{Gd}_{0.1} \mathrm{O}_{2-\delta}$ as a function of oxygen vacancy concentration

\section{5. 結 言}

全固体型エネルギー変換デバイス用構成材料の評価法ならびに設計法の確立を目指し，酸素分圧(酸化-還 
元)ならびに温度(室温 $\left.-1000^{\circ} \mathrm{C}\right)$ を制御し, 縦弾性係数, 破壊強度, クリープ特性ならびに疲労特性等の機械的 性質がその場で評価できる装置を開発した。開発した装置を用いて, 不定比性酸化物材料である $\mathrm{Ce}_{0.9} \mathrm{Gd}_{0.1} \mathrm{O}_{2-\delta}$ の久陥濃度と機械的特性に関する検討を行った. $\mathrm{Ce}_{0.9} \mathrm{Gd}_{0.1} \mathrm{O}_{2-\delta}$ の破壊強度は縦弹性係数の傾向とは異なり, 酸 素分圧(酸素欠陥濃度)との相関は見られなかった。これは, クエンチ処理を施した SP 試験法の結果とは相反 する結果となった。これにより動作環境下における機械的特性評価の重要性を示すことができた. 破壊特性 については, 酸素欠陥により誘起するカチオン-アニオンの結合力低下とトレードオフ寸る何らかの上昇要因 (電子構造等)が起因していることが推測されるが原因を特定するためには更なる解析を要する. 酸素不定比 性材料である $\mathrm{Ce}_{0.9} \mathrm{Gd}_{0.1} \mathrm{O}_{2-\delta}$ は還元環境に唒されることによりの酸素欠陥を生じ, In-situ SP 試験で酸素欠損量 と機械的特性(縦弾性係数)は相関関係があることが分かった。

\section{謝 辞}

本研究の成果は, 新エネルギー・産業技術総合開発機構(NEDO)の委託業務ならびに文部科学省科学研究費 若手研究(B)(18860001)により得られたものである. また, 装置開発は東北大学多元物質科学研究所技術室機 械工場の柳田里見氏, 朝倉和也氏ならびにインストロンジャパンカンパニイリミテッドの高崎新平氏と秋山 邦洋氏の協力を得た.ここに謝意を表す.

\section{参 考 文 献}

(1) S.Wang, M.Katsuki, T.Hashimoto, M.Dokiya, "Expansion behavior of $\mathrm{Ce}_{1-y} \mathrm{Gd}_{y} \mathrm{O}_{2.0-0.05 y-\delta}$ under various oxygen partial pressures evaluated by HTXRD”, Journal of The Electrochemical Society, Vol150, No7(2003), pp.A952-A958.

(2) Y.Xiong, K.Yamaji, T.Horita, N.Sakai,and H.Yokokawa, "Hole and electron conductivities of $20 \mathrm{~mol} \%-\mathrm{REO}_{1.5}$ doped $\mathrm{CeO}_{2}(\mathrm{RE}=\mathrm{Yb}, \mathrm{Y}, \mathrm{Gd}, \mathrm{Sm}, \mathrm{Nd}, \mathrm{La})$ ), Journal of the Electrochemical Society, Vol.151,No.3 (2004), pp.A407-A412.

(3) H. Yakabe, M. Hishinuma, and I. Yasuda, "Static and Transient Model Analysis on Expansion Behavior of $\mathrm{LaCrO}_{3}$ under an Oxygen Potential Gradient", Jounal of the Electrochemical Society, Vol.147, No11 (2000), pp.4071-4077.

(4) K.Yasumoto, M.Shiono, H.Tagawa, M.Dokiya, K.Hirano, J.Mizusaki, "Effect of Oxygen Nonstoichiometry on a $\mathrm{La}_{1-x} \mathrm{~A}_{x} \mathrm{MnO}_{3+\delta}$ Cathode under a Polarized State", Jounal of the Electrochemical Society, Vol.149, No5(2002), pp.A531-A536.

(5) A.Atkinson, A.Selcuk, "Mechanical behavior of ceramic oxygen ion-conducting membranes", Solid State Ionics, Vol.134 (2000), pp.59-66.

(6) A. Atkinson, "Chemically-induced stresses in gadolinium-doped ceria solid oxide fuel cell electrolytes", Solid State Ionics, Vol.95 (1997), pp.249-258.

(7) S.Sameshima, T.Ichikawa, M.Kawaminami, Y.Hirata, "Thermal and mechanical properties of rare earth-doped ceria ceramics", Materials Chemistry and Physics, Vol.61(1999), pp.31-35.

(8) “JIS ハンドブック”, 日本規格協会 35(2002) セラミック,p243.

(9) R. Krishnamurthy, B. W. Sheldon, "Stresses due to oxygen potential gradients in non-stoichiometric oxides", Acta Materialia, Vol.52-7 (2004), pp1807-1822.

(10) 奥田誠一, 斉藤雅弘, 橋田俊之, 高橋英明, “傾斜機能材料のための小型パンチ試験法に関する研究”, 日 本機械学会論文集 A 編, Vol.57, No.536(1991-4), pp.940-945.

(11) 斎藤雅弘, 高橋英明, 鄭熙敦, 川崎亮, 渡辺龍三, “微小試験片法による金属/セラミック複合材料の破壊 勒性評価”，日本機械学会論文集 A 編, Vol.57, No.535(1991-3), pp.522-529.

(12) Y.Wang, K. Duncan, E. D.Wachsman, F. Ebrahimi, "The effect of oxygen vacancy concentration on the elastic modulus of fluorite-structured oxides", Solid State Ionics, Vol.178 (2007), pp.53-58.

(13) K.Yashiro, S.Onuma, A.Kaimai, Y.Nigara, T.Kawada, J.Mizusaki, K.Kawamura, T.Horita, H.Yokokawa, "Mass transport properties of $\mathrm{Ce}_{0.9} \mathrm{Gd}_{0.1} \mathrm{O}_{2-\delta}$ at the surface and in the bulk", Solid State Ionics, Vol.152- 153 (2002), pp.469-476. 